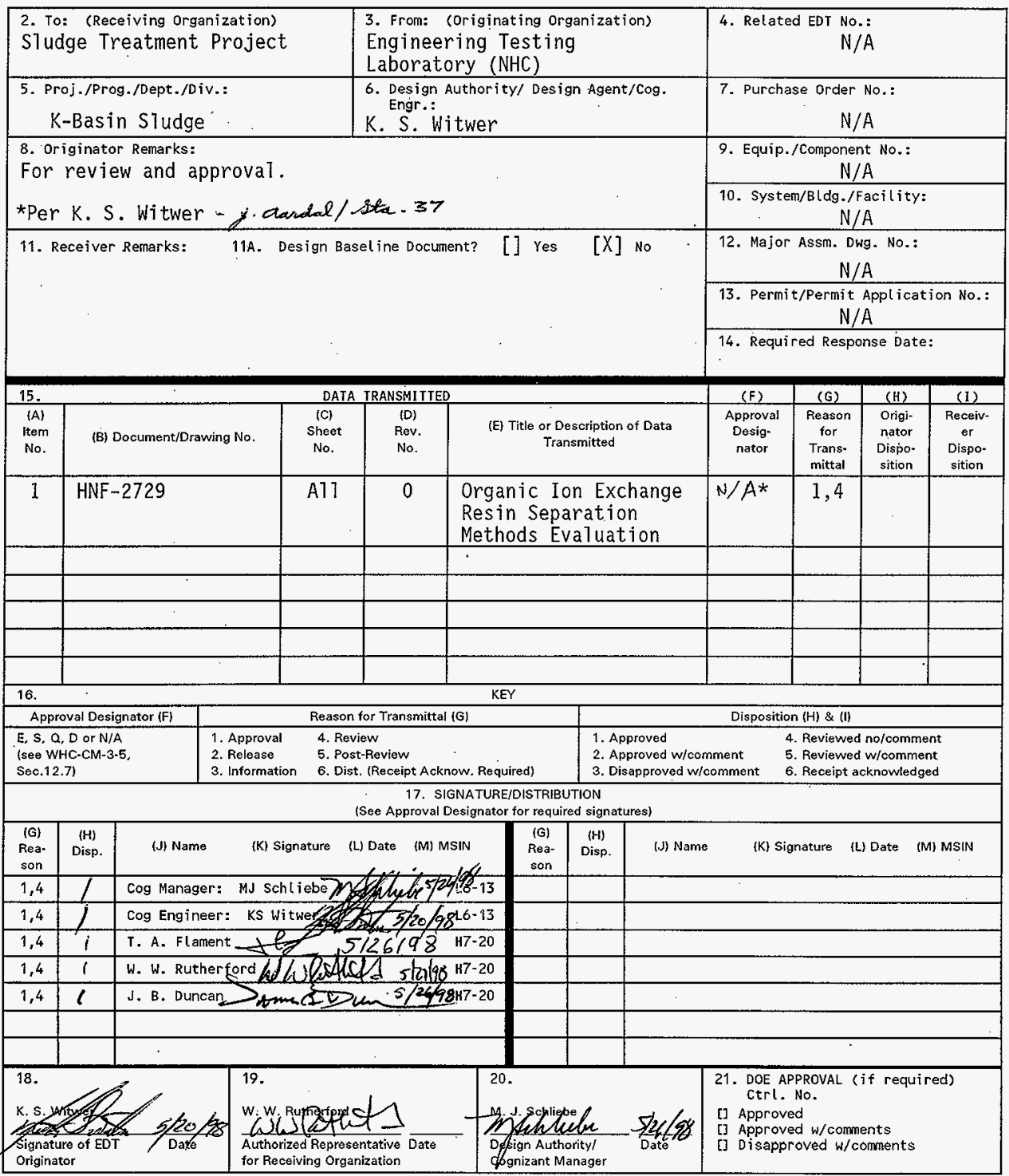


HNF-2729, Rev. 0

\section{ORGANIC ION EXCHANGE RESIN SEPARATION METHODS EVALUATION}

Keith S. Witwer

Numatec Hanford Corporation, Richland, WA 99352

U.S. Department of Energy Contract DE-AC06-96RL13200

EDT/ECN: $618464 \quad$ UC: 506

Org Code: 8C700 Charge Code: LD453

B\&R Code: EW7040000 Tota1 Pages: 28 29

Key Words: Organic Ion Exchange Resin, Separation Methods, Testing, Analysis, Data

Abstract: This document describes testing to find effective methods to separate Organic Ion Exchange Resin (OIER) from a sludge simulant. This task supports a comprehensive strategy for treatment and processing of $\mathrm{K}$-Basin sludge. The simulant to be used resembles sludge that has accumulated in the 105KE and 105KW Basins in the 100K area of the Hanford Site. The sludge is an accumulation of fuel element corrosion products, organic and inorganic ion exchange materials, canister gasket materials, iron and aluminum corrosion products, sand, dirt, and other minor amounts of organic matter.

TRADEMARK DISCLAIMER. Reference herein to any specific commercial product, process, or service by trade name, trademark, manufacturer, or otherwise, does not necessarily constitute or imply its endorsement, recomendation, or favoring by the United States Government or any agency thereof or its contractors or subcontractors.

Printed in the United States of America. To obtain copies of this document, contact: Document Control Services, P.0. 80x 950, Mailstop H6-08, Richland WA 99352, Phone (509) 372-2420; Fax (509) 376-4989.
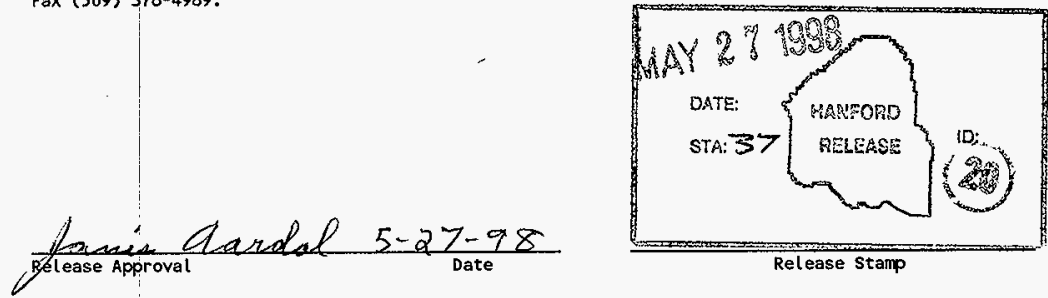

Release Stamp 


\title{
ORGANIC ION EXCHANGE RESIN SEPARATION METHODS EVALUATION
}

\author{
HNF-2729 \\ Rev. 0 \\ May 19,1998
}

Keith S. Witwer

Engineering Testing Laboratory

Numatec Hanford Corporation

Richland, Washington 


\section{TABLE OF CONTENTS}

Page

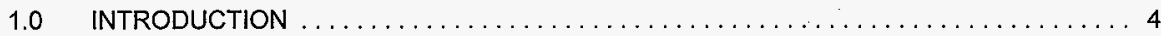

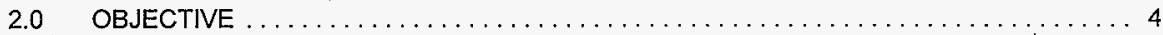

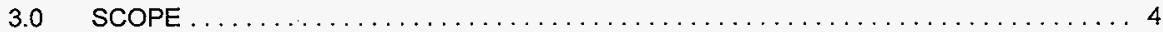

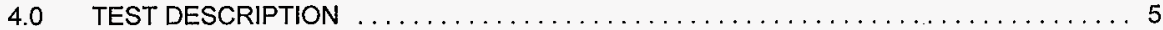

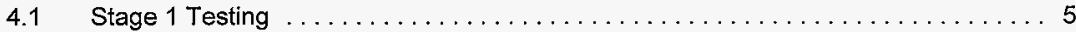

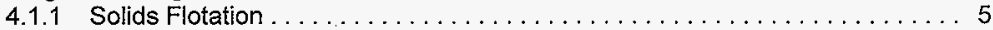

4.1 .2 Hydro Cycione $\ldots \ldots \ldots \ldots \ldots \ldots \ldots \ldots \ldots \ldots \ldots \ldots \ldots, \ldots, \ldots$

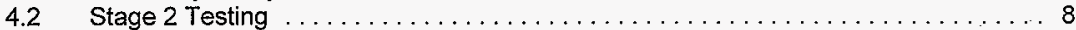

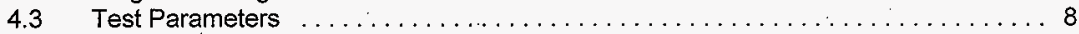

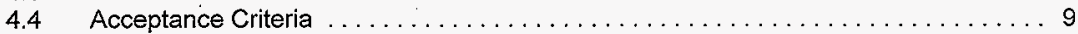

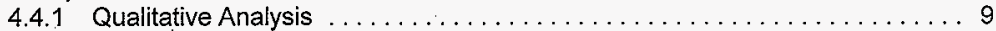

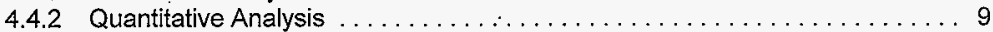

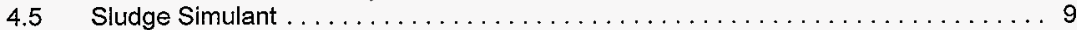

4.6 Test Environment ............................................. 10

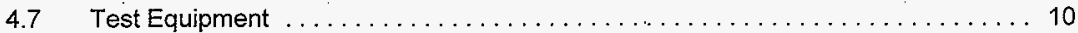

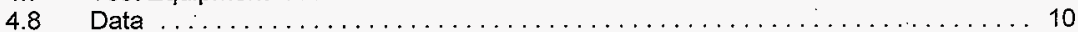

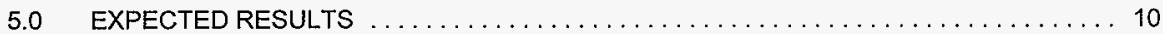

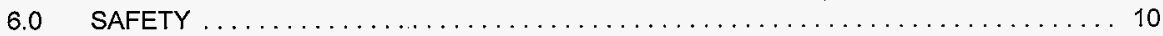

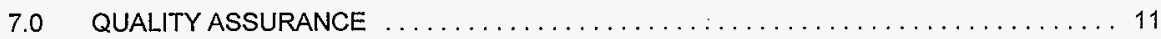

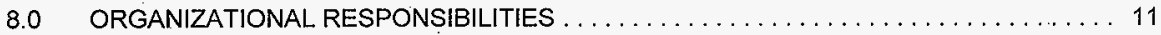

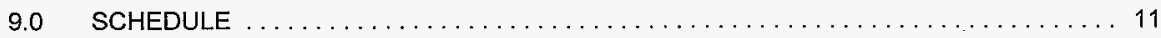

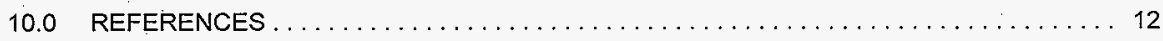

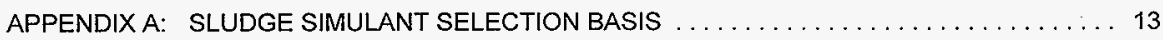

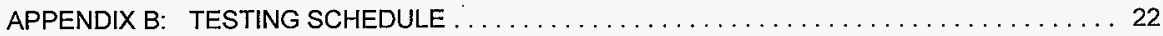


HNF-2729

Rev. 0

PAGE 3 OF 28

\section{LIST OF FIGURES}

Figure 1: $\quad$ Sketches of Solids Flotation Methods $\ldots \ldots \ldots \ldots \ldots \ldots \ldots \ldots \ldots \ldots \ldots \ldots \ldots \ldots \ldots$

Figure 2: Hydro Cyclone with main flow pattern $\ldots \ldots \ldots \ldots \ldots \ldots \ldots \ldots \ldots \ldots \ldots \ldots \ldots$ 


\section{ORGANIC ION EXCHANGE RESIN SEPARATION METHODS EVALUATION}

\subsection{INTRODUCTION}

This document describes testing to find effective methods to separate Organic lon Exchange Resin (OIER) from a sludge simulant. This task supports a comprehensive strategy (Flament 1998) for treatment and processing of $\mathrm{K}$ Basin sludge. The simulant to be used, described in Appendix $A$, resembles sludge that has accumulated in the 105KE and 105KW Basins in the $100 \mathrm{~K}$ area of the Hanford Site. The sludge is an accumulation of fuel element corrosion products, organic and inorganic ion exchange materials, canister gasket materials, iron and aluminum corrosion products, sand, dirt and other minor amounts of organic matter.

Final process treatment will involve separation of the sludge from any solid material by passing through a $1 / 4$ inch mesh screen. This will be followed by chemical treatment before being stored in tank AW-105 at the Hanford Tank Farms. Undesirable chemical reactions occur with the OIER when the sludge is chemically processed (with nitric acid) however. Thus, the majority of the OIER needs to be removed from the sludge prior to chemical processing while also minimizing the amount of sludge entrained with the separated OIER. The resin can then be separately treated and disposed of as appropriate.

\subsection{OBJECTIVE}

The objective is two-staged. The first stage is to separate OIER from a standard sludge simulant via bench testing of several separation technologies. Separating the OIER from the sludge could be difficult due to the size/density distribution of particles in the sludge. The OIER is relatively large but low in density compared to the other smaller but heavy particles such as the sand.

The second stage will involve more detailed proof-of-principle testing using variations on the standard sludge simulant. Results from this testing will feed later validation "hot testing" using actual K-Basin sludge mixtures.

\subsection{SCOPE}

This testing is directed by Numatec Hanford Corporation (NHC) Sludge Treatment Project (STP) per NHC Internal Memo (Rutherford 1998) and will be done by the NHC Engineering Testing Laboratory (ETL) under Task Package Control Number LD453. It follows the testing strategy outlined in HNF-2574, "Testing Strategy to Support the Development of K Basins 
Sludge Treatment Process," - specifically section 4.1. The testing is primarily of a bench scale nature and will use only non-radioactive components.

\subsection{TEST DESCRIPTION}

As mentioned previously, the testing will be broken into two parts or stages. Stage 1 will involve general scoping tests of several separation methods. This will involve using a baseline simulant recipe that will be used for each separation method. Results from each method will be compared against the acceptance criteria (described in section 4.4) with follow-on Stage 2 testing focusing on refinement of operating parameters. This will involve more extensive testing with the chosen separation methods, possibly altering parameters such as the sand/OIER ratio, simulant flow rates through the device, etc.

\subsection{Stage 1 Testing}

Many methods for solid separation are commercially available. Of these, only a few are considered appropriate and/or are readily available for this testing given the cost and schedule constraints. These selected methods are:

\section{- Solids Flotation \\ - Hydro Cyclone}

Other methods, such as Lamella tube settling and screen filtration may be investigated if time permits and should be included in an engineering study for further consideration.

Brief functional descriptions of the selected methods are given below:

\subsubsection{Solids Flotation}

Flotation techniques take advantage of the variation in solids settling characteristics to achieve separation of particles and result in classification of particles fundamentally based on their physical properties. Three different flotation approaches will be evaluated:

1) Air Lift

2) Elutriation

3) Agitated Slurry

Each technique uses a different mechanism to achieve solids separation. Refer to Figure 1 for a sketch of each process. The airlift separator (ALS) uses finely distributed air/gas affectively to alter the liquid density and promote upward entrainment of solids. Adjusting air flow and bubble size are key parameters affecting solids separation characteristics. The 


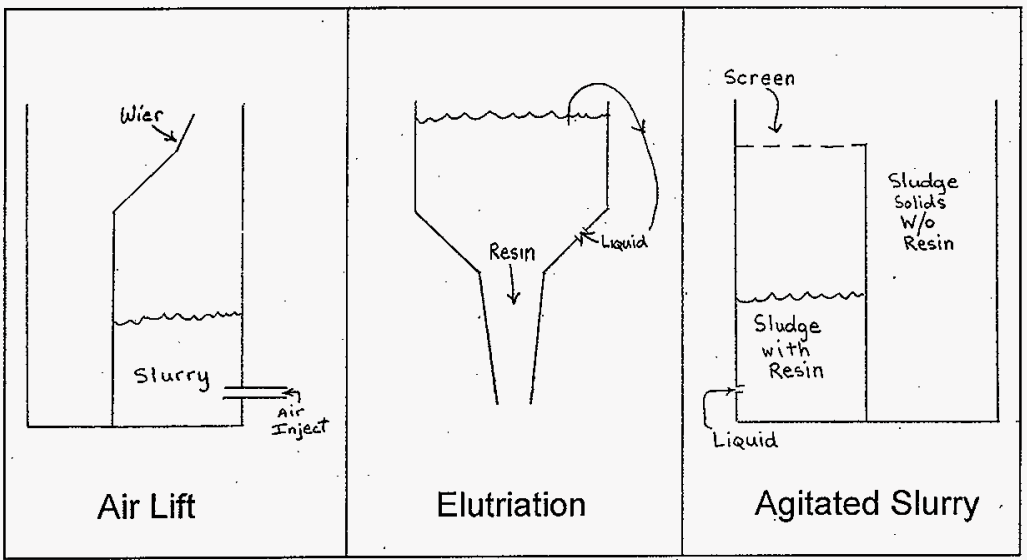

Figure 1: - Sketches of Solids Flotation Methods

rising air causes the resin to float and be skimmed off over a weir into a catch basin. Water going over the weir can be filtered out and recycled into the original container. Elutriation uses upward liquid flows to entrain solids with lower settling velocities (fine sludge) while allowing those with higher settling velocities (OIER) to settle. The agitated slurry method also uses an injected liquid flow to suspend and separate fine sludge particles from resin beads. A coarse screen would be sized to retain the larger resin beads and allow fine particles to pass.

\subsubsection{Hydro Cyclone}

The hydro cyclone is closely related both to the gravity settling tank and the sedimenting centrifuge. The function of the hydro cyclone is shown in Figure 2. A feed stream enters through the tangential inlet, generating a scroll-like flow along the inner surface of the cyclone body; this is the primary vortex flow. The apex, or underflow nozzle, prevents the discharge of the total flow, and causes the upwards secondary vortex flow into the overflow outlet nozzle. The primary vortex, with its relatively low centrifugal forces causes the coarser particles to settle toward the wall. Both the circumferential speed and the angular velocity are much higher in the secondary vortex than in the primary vortex, thus generating high centrifugal forces that induce settlement of the fine particles in a radial direction. These fine particles join the primary settled coarse ones and move with them along the wall toward the apex, then to be discharged as a concentrated but fluid stream. Part of the secondary settled finer particles are recycled internally, thus giving a good washing effect that results in a relatively sharp separation. 
Rev. 0

PAGE 7 OF 28

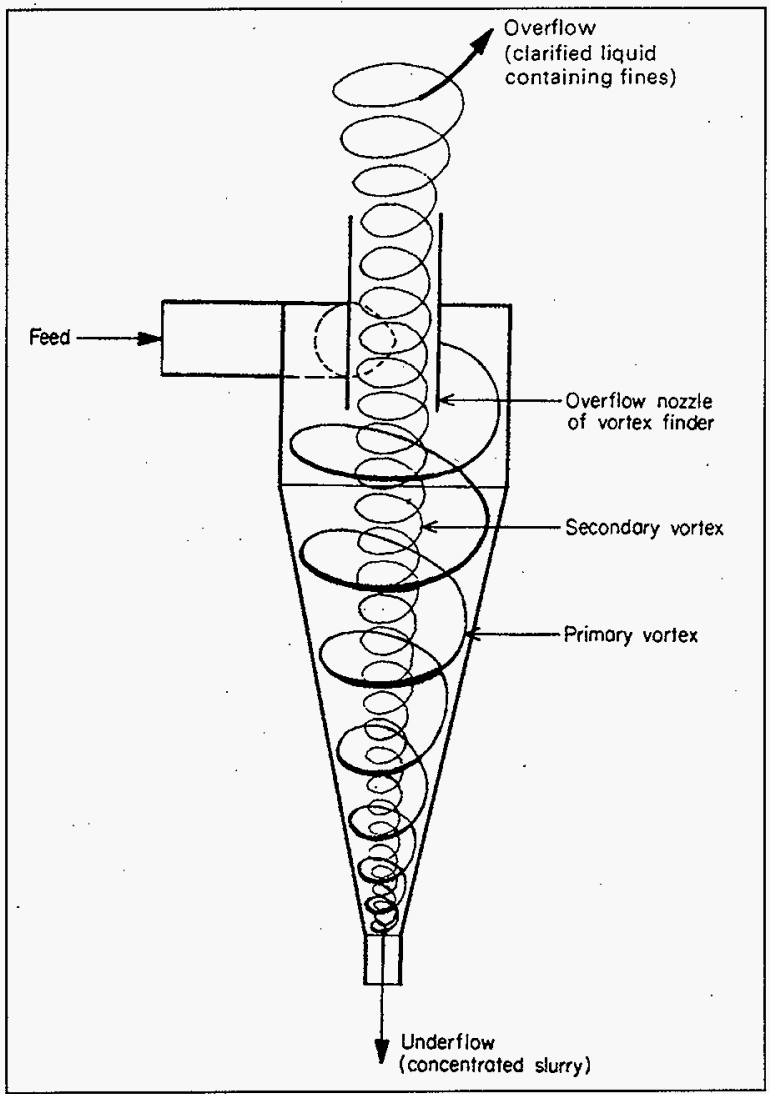

Figure 2 Hydro Cyclone with main flow pattern

Each of the stated methods may be used as a first stage filtration process with devices added downstream for final particle separation. 


\subsection{Stage 2 Testing}

Stage 2 will involve assessment of results from Stage 1 testing; refinement of equipment as test results indicate; additional proof-of-principle tests to confirm assumptions; and development of procurement specs for commercially available equipment. As mentioned, test parameters will be altered to verify the technology under varying conditions.

\subsection{Test Parameters}

Some key test parameters for each separation method are listed in Table 1. Modification of independent variables for each separation method which. will affect the efficiency of the device in terms of the most important variable - OIER capture. This, along with any residual sludge captured are the two common dependant variables common to all of the separation methods. Other dependant variables, such as particle terminal velocity for the ALS or underflow velocity for the hydro cyclone are unique to each method. The significance in knowing and measuring these values is that later conceptual design will need the information for design purposes.

Table 1 - Test Parameters

\begin{tabular}{|c|c|c|}
\hline $\begin{array}{l}\text { Separation } \\
\text { Method }\end{array}$ & Independent Variables & Dependant Variables \\
\hline $\begin{array}{l}\text { Solids } \\
\text { Flotation }\end{array}$ & $\begin{array}{l}\text { volumetric air flow rate; } \\
\text { gas bubble size; } \\
\text { water flow rate; } \\
\text { mixing configuration; } \\
\text { vessel dimensions; } \\
\text { resin concentration; } \\
\text { blow sand concentration; }\end{array}$ & 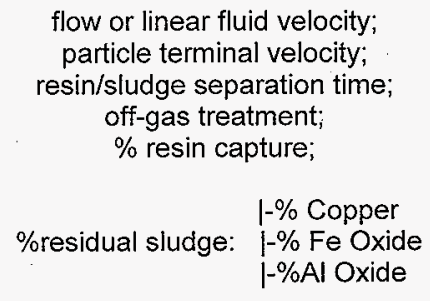 \\
\hline $\begin{array}{l}\text { Hydro } \\
\text { Cyclone }\end{array}$ & $\begin{array}{c}\text { vessel dimensions (inlet \& outlet port } \\
\text { diameters, cone angle, cylinder } \\
\text { length); } \\
\text { tangential inlet pressure; } \\
\text { resin concentration; } \\
\text { blow sand concentration; }\end{array}$ & $\begin{array}{c}\text { Underflow and overflow } \\
\text { volumetric rates; } \\
\text { resin/sludge separation time; } \\
\% \text { resin capture } \\
\text { \%residual sludge: } \begin{array}{l}\mid-\% \text { Copper } \\
\text { |-\% Fe Oxide } \\
1-\% \text { Al Oxide }\end{array}\end{array}$ \\
\hline
\end{tabular}


The percent resin and percent residual sludge are the dependant variables of interest. Other dependent variables are related to or feed this variable.

\subsection{Acceptance Criteria}

The acceptance criteria for the chosen method is the ability of the selected method to separate at least $95 \%$ of the OIER from the sludge simulant. In addition, criteria for carryover of the sludge fines with the resin shall be no more than $5 \%$ of the total sludge fines. The acceptance criteria may be modified later by STP based on information (such as equipment limitations) discovered during testing.

\subsubsection{Qualitative Analysis}

Success of a given method would initially be qualitative in nature. Visual inspection of the separated slurry for total percentage of OIER should provide adequate information to rank one method over another.

\subsubsection{Quantitative Analysis}

Quantitative inspection of the separated mixture would involve such methods as mass balance analysis. The mass of a unit volume of the dry OIER before mixing with other simulant components will be determined as a reference point. The resin will then be mixed with the sludge simulant to allow fine particulate to adhere to the resin bead surface. The resin will be separated from the sludge quantitatively and washed to remove loosely adhered sludge particulate from the resin bead surface. The unit mass of the resin will again be measured to determine the nominal mass offset due to residue adhesion to the resin surface. Sufficient replicates will be performed to determine if there is constant positive mass increase. This data will be used to adjust the mass percent residual sludge carry-over.

\subsection{Sludge Simulant}

The simulant to be used for testing has been defined (Duncan 1998) and a copy of the selection basis is included in Appendix A. The particle size distribution for the simulant is also defined in Appendix $A$ and is in accordance with particle size distribution of the samples taken from the K East main floor basin and the "Weasel Pit." The sludge simulant components (by weight percentages) are defined as:

- Copper

- Iron Oxide

- Aluminum Oxide

- Water

- Blow Sand \& Purolite OIER
$2.5 \%$

$10.8 \%$

$1.8 \%$

$56.8 \%$

$28.1 \%$ 
Note that except for the copper, these components closely mimic those found in $\mathrm{K}$ Basin sludge. Copper will be used in place of uranium oxide because it is readily available, has a specific gravity (8.9) relatively close to uranium oxide (10.96), and will eliminate the radiation hazard. Initially a $50 / 50$ mixture $(14.05 \%$ each) of the blow sand and OIER will be used. This will provide a baseline recipe for use in each of the separation methods. The blow sand/OIER ratio will be altered in the second phase of testing (somewhere between a 10/90 to $90 / 10$ ratio) once a final separation method has been identified.

\subsection{Test Environment}

Testing of any of the above proposed methods will be done at the Engineering Testing Laboratory located in the 305 Building, 300 Area, Richland, WA.

\subsection{Test Equipment}

Test equipment that will be needed may include flow meters, pressure gages, mass balances, temperature indicators, data acquisition systems, etc. Each item used for measurement will be verified for accuracy. When available, either currently calibrated equipment or accepted primary standard will provide verification.

\subsection{Data}

Pertinent test data to be measured will include items such as sludge solids concentrations, separated OIER weight percentages, flow rate, temperature, etc. These will be recorded in controlled laboratory logbook number HNF-N-132-1. Data will also be collected electronically using a data acquisition system where appropriate. Data measuring equipment information will also be recorded which will include information such as equipment type and specification, test results and observations, sketches and photos, etc.

\subsection{EXPECTED RESULTS}

These tests are expected to identify one or more methods for adequate separation of OIER from a K-Basin sludge simulant. This selected method(s) will be presented as candidates for additional proof testing using variations of the simulant.

\subsection{SAFETY}

Standard ETL safety practices will be enforced. This includes the proper use of pertinent personal protection equipment, such as safety glasses and face shield, steel toed shoes, 
protective lab coat or apron, etc. A Job Hazard Analysis (JHA) will be produced identifying any specific hazards and will be reviewed by all test personnel before any testing may commence. The test director will conduct a pre-job meeting and is responsible for ensuring that all personnel involved are properly trained and aware of any hazards present. An Industrial Safety representative will review the JHA and associated testing apparatus prior to testing.

\subsection{QUALITY ASSURANCE}

Since these tests are of scoping nature, standard QA oversight and review of procedures is not applicable. Standard laboratory controls such as measuring equipment verification, calibration (where possible), etc., will be in place to assure quality control. Later verification testing will incorporate QA oversight as needed.

\subsection{ORGANIZATIONAL RESPONSIBILITIES}

\section{Engineering Testing Laboratory - NHC}

The ETL is responsible for providing test personnel, equipment, OIER separation equipment, test direction, and final test report writing and release. The Cognizant Manager is Michael Schliebe and the Test Engineer/Technical Lead is Keith Witwer.

\section{Sludge Treatment Project - NHC}

The Sludge Treatment Project is providing funding and direction for this testing. The Project Manager is Wallace W. Rutherford and the Technical Lead is Thierry A. Flament.

\section{Chemical Engineering - COGEMA Engineering Corporation}

Jim Duncan will provide chemical engineering and particle separation research support as needed. Don Gana, a COGEMA Engineering technician, will provide simulant preparation support as well as any equipment setup support as needed.

\subsection{SCHEDULE}

Scoping tests will begin as soon as simulant is made and OIER separation devices are setup. An interim report is scheduled for June 5, 1998 followed by a final supporting document test report due on June 28, 1998. A Sludge Treatment Projects schedule, which lists this testing, is included in Appendix B. 


\subsection{REFERENCES}

FLAMENT 1998, Testing Strategy to Support the Development of K Basins Sludge Treatment Process, HNF-2574, April 1998.

RUTHERFORD 1998, Letter of Instruction \#STP-002 For Organic lon Exchange Resin Separation Cold Testing, 8C720-98-WWR-002, May 1998.

DUNCAN 1998, Internal Memo - Sludge Simulant for Organic lon Exchange Resin Separation, 8C720-98-JBD-001, April 1998. 
PAGE 13 OF 28

\section{APPENDIX A: SLUDGE SIMULANT SELECTION BASIS}


NHC

Numatec

HNF-2729

Rev. 0

Hanford Corporation

Page 14 of 28

An SGN/Cogema, Inc. Company

Internal

Memo

From:

J. B. Duncan JAD

8C720-98-JBD:001

Phone: $\quad 372-0896$ H7 -20

Date: April 23, 1998

Subject:

SLUDGE SIMULANT FOR ORGANIC ION EXCHANGE RESIN SEPARATION

To:

T. A. Flament

H7-20

cc:

K. L. Pearce

$\mathrm{H} 7-20$

M. J. Schliebe

L6-13

References: (1) Article, "Aralysis of Sludge from Hanford K East Basin Floor and Weasel Pit," WHC-SP-1182, dated April 1996.

(2) Article, K. Willeke and K.T. Whitby, J. Air Pollution Control Assoc., Vol. 25 p. 529 , dated 1975.

(3) Book, Kirk-Othmer, Encyclopedia of Chemical Technology, Vol. 1 (4th Ed.), 1991.

(4) Book, edited by R. C. Weast, CRC Handbook of Chemistry and Physics, 53rd Ed., 1972-1973

(5) Technical Data Sheet, Purolite NRW-37 Nuclear Grade Resin.

\section{Purpose}

The purpose of this memorandum is to put forth a selection basis for the $\mathrm{K}$ East Basin floor and Weasel Pit simulant for the organic ion exchange resin (OIER) separation unit operation.

\section{K East Sludge and Weasel Pit}

Using Table 4.3 Sludge Characterization Data -- Per Gram As-Settled Sludge (WHC-SP-1182), the following mean values were extracted:

Table $1^{\mathrm{A}}$ Sludge Characterization Data

\begin{tabular}{|l|c|}
\hline & - \\
\hline Inorganic Elements & 13.4 \\
\hline Water & $56.8^{\mathrm{B}}$ \\
\hline Uranium & $2.5^{\mathrm{C}}$ \\
\hline Acid Insoluble Residue & 8.25 \\
\hline
\end{tabular}




\begin{tabular}{|l|c|}
\hline Total & ren \\
\hline Major Inorganic Elements $(>1 \%)$ & 80.95 \\
\hline
\end{tabular}

A The values are "as settled sludge", the expected water content of the retreived sludge is expected to be at a.much higher concentration.

${ }^{B}$ Averaged values from $222 \mathrm{~S} L \mathrm{Lab}$ and PNNL.

${ }^{\mathrm{c}}$ ICP for total U, 222S Lab

The total analysis does not sum to $100 \%$. This is due to some elements not being analyzed, such as Si. Silicon did appear in compounds detected by XRD analysis. For example, some of the compounds reported were: $\mathrm{SiO}_{2}, \mathrm{Mg}_{3} \mathrm{Si}_{4} \mathrm{O}_{10}(\mathrm{OH})_{2}, \mathrm{Si}, \mathrm{CaAl}_{2} \mathrm{Si}_{2} \mathrm{O}_{8} \cdot 4 \mathrm{H}_{2} \mathrm{O}$. Also, the analysis ignored the mass contribution of bound water (water of hydration).

In Appendix I (WHC-SP-1182), the particle size analysis indicated that the samples were measured "as received", after sonication at $25 \mathrm{~W}(120 \mathrm{sec}$ ), and after sonication at $40 \mathrm{~W}$ (300 sec.). The data taken into consideration for this report will be the "as received" data for simulant formulation. The use of "as received" data is due to the fact that the sludge retrieval mechanism is not yet know. Appendix A of this memorandum is an analysis of the graphical data presented in Appendix I of WHC-SP-1182, for the "as received" and sonicated samples.

\section{Assumptions}

1. The separations will be based on physical parameters of the floor and weasel pit sludge.

2. The analyses as reported in WHC-SP-1182 are correct.

3. The fully loaded resin beads have a negligible increase in density (phone conversation with a Purolite Tech Representative, (800) 343-1500).

4. The mean mass balance difference of $19.05 \%$ ( $100 \%$ minus $80.95 \%$ from Table 1 ) is due to the mass contribution of compounds that were not considered for analyses (silicon for example), bound water, and ion exchange resin:

5. The resin is Purolite NRW-37 Nuclear Grade, mixed bed. The density of the hydrogen form (cation exchange resin) is 1.24. The density of the $\mathrm{Cl}$ form (anion exchange resin) is 1.10. The mesh size is 16 to 40 , US standard screen (1.19 to $0.42 \mathrm{~mm}$, respectively).

6. Blow sand in the range of 2.5 to 10 microns (See Appendix B).

7. The only radionuclide of mass consequence is Uranium.

8. The simulant will be derived from the mean values as reported in Table 4.2 (WHC-SP-1182). Adjustments will be made to mimic various conditions. 
T. A. Flament

8C720-98-JBD:001

Page 3

HNF-2729

April 23, 1998

Rev. 0

Page 16 of 28

\section{Selection of the Simulant for OIER separation}

Table 2 Major Analytes and Simulants

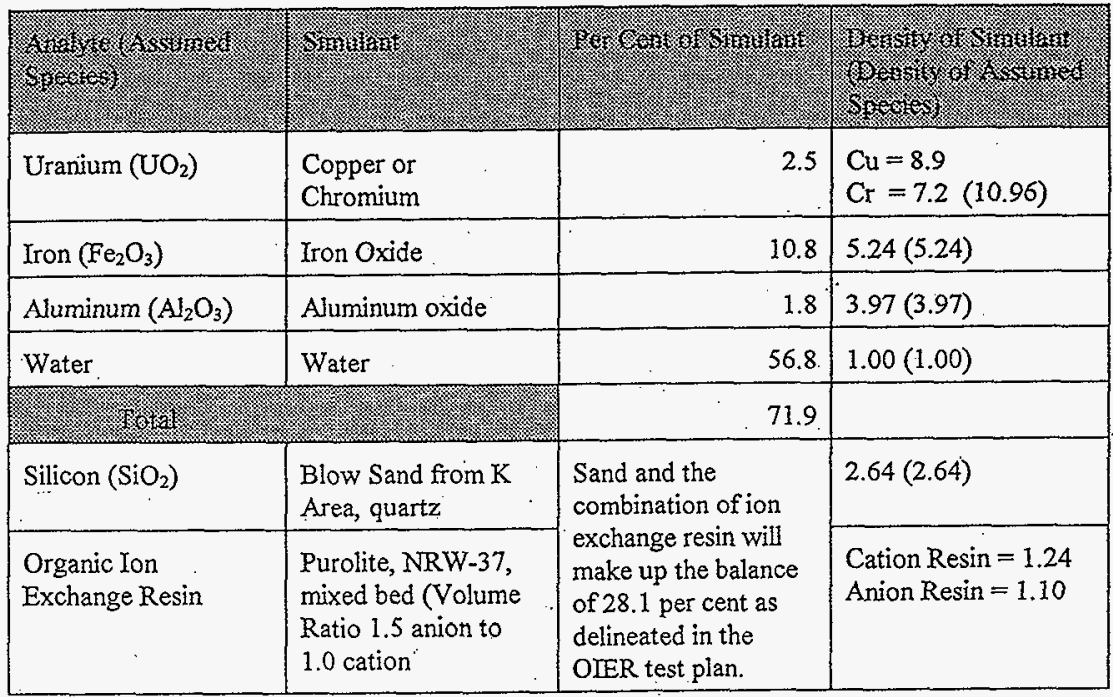

\section{Laboratory Protocol for Simulant Make-up}

Materials:

- Resin: Resin beads will be obtained from either the vendor or from $\mathrm{K}$ Basin operations.

- Aluminum oxide, chromium (or copper) will be obtained from a vendor in varying particle. dimensions.

- Iron oxide will be obtained by physically scraping "rusted material" found in storage yards around Bldg. 305, 306E, etc.

- Blow sand will be obtained by retrieving the top 2 to $3 \mathrm{~mm}$ of sand around the K East basin.

- Water will be de-ionized, conductivity and $\mathrm{pH}$ will approximate that of $\mathrm{K}$ East basin.

Preparation:

- Grinding:

Individually, the iron oxide, aluminum oxide, and the blow sand will be subjected to a grinding phase such as a ball mill or similar apparatus. 
T. A. Flament

8C720-98-JBD:001

Page 4

HNF-2729

April 23, 1998

All material will individually be classified using a Rotap; with screen sizes from 25 US Standard mesh $(710 \mu \mathrm{m})$ to 400 US Standard mesh $(37 \mu \mathrm{m})$. Material passing the 400 mesh will be collected as 400 minus and subjected to particle analysis.

- Simulant Make-up

Example:

The resin and sand are dependent variables and will vary according to the test protocol. However, the concentrations for iron oxide, aluminum oxide, water, and chromium will be fixed (assumption -- normally and independently distributed, $(0,1)$ ).

For a total of $1000 \mathrm{~g}$ of simulant, and using the particle volume distribution for M13B (Appendix A, Table A-2, as received), particle diameters from $31 \mu \mathrm{m}$ to $352 \mu \mathrm{m}$ (mesh size of 400 to 48 respectively). The following table can be derived. The weight of simulant should sum to the gram fraction of $1000 \mathrm{~g}$ as indicated. The difference between the independent variables and the total grams required for that particle range will be made from the dependent variables (resin and sand). 
Table 3 Example of Simulant Make-up (1000 g)

\begin{tabular}{|c|c|c|c|c|c|c|c|c|}
\hline Mesh Size & $48-60$ & $60-80$ & $120-80$ & $170-120$ & $230-170$ & $325-230$ & $400-325$ & $<400$ \\
\hline $\begin{array}{l}\text { Particle } \\
\text { Diameter } \\
\text { (Dm) }\end{array}$ & $248-352$ & $176-248$ & $125-176$ & $88-125$ & $62-88$ & $44-62$ & $37-44$ & $<37$ \\
\hline $\begin{array}{l}\text { Per Cent } \\
\text { Particles in } \\
\text { Range }\end{array}$ & $\begin{array}{l}1.3 \\
(13 \mathrm{~g})\end{array}$ & $\begin{array}{l}3.3 \\
(33 \mathrm{~g})\end{array}$ & $\begin{array}{l}3.9 \\
(39 \mathrm{~g})\end{array}$ & $\begin{array}{l}5.5 \\
(55 \mathrm{~g})\end{array}$ & $\begin{array}{l}7.9 \\
(79 \mathrm{~g})\end{array}$ & $\begin{array}{l}9.7 \\
(97 \mathrm{~g})\end{array}$ & $\begin{array}{l}10.1 \\
(101 \mathrm{~g})\end{array}$ & $\begin{array}{l}58.3 \\
(583 \mathrm{~g})\end{array}$ \\
\hline $\begin{array}{l}\mathrm{Al}_{2} \mathrm{O}_{3} @ \\
1.8 \%(\mathrm{~g}) \\
\end{array}$ & 0.23 & 0.60 & 0.70 & 0.99 & 1.4 & 1.7 & 1.8 & \\
\hline $\begin{array}{l}\mathrm{Fe}_{2} \mathrm{O}_{3} @ \\
10.8 \%(\mathrm{~g})\end{array}$ & 1.4 & 3.6 & 4.2 & 5.9 & 8.5 & 10.5 & 10.9 & \\
\hline $\begin{array}{l}\mathrm{Cr} @ \\
2.5 \%(\mathrm{~g}) \\
\end{array}$ & 0.33 & 0.83 & 0.98 & 1.38 & 1.9. & 2.4 & 2.5 & \\
\hline $\begin{array}{l}\text { Water@, } \\
56.8 \%(\mathrm{~g})\end{array}$ & 7.4 & 18.7 & 22.2 & 31.2 & 44.9 & 55.1 & 57.4 & \\
\hline Total & 9.4 & 23.7 & 28 & 39.5 & 55.3. & 69.7 & 72.6 & \\
\hline $\begin{array}{l}\text { Difference } \\
\text { to be made } \\
\text { up with } \\
\text { Resin and } \\
\text { Blow Sand } \\
\text { (g) }\end{array}$ & 3.6 & 9.3 & 11 & 15.5 & 23.7 & 27.3 & 28.4 & \\
\hline
\end{tabular}


T. A. Flament

Page 6

April 23, 1998
8C720-98-JBD:001

MNF -2729

Rev. 0

Page 19 of 28

\section{APPENDIX A}

Analyses of Particle Number Distribution and Particle Volume Distribution Graphs from Appendix I, WHC-SP-1182

Table A-1 Particle Number Distribution (WHC-SP-1182, Appendix I)

\begin{tabular}{|c|c|c|c|c|c|c|c|c|c|c|c|c|}
\hline \multirow{3}{*}{$\begin{array}{l}\text { Particle } \\
\text { Dia. } \\
\text { (Dm) }\end{array}$} & \multicolumn{3}{|c|}{ M13T } & \multicolumn{3}{|c|}{ M13B } & \multicolumn{3}{|c|}{$\mathrm{T} 20 \mathrm{~T}$} & \multicolumn{3}{|c|}{ T20B(Duplicate) } \\
\hline & \multicolumn{3}{|c|}{ Per Cent in Range } & \multicolumn{3}{|c|}{ Per Cent in Range } & \multicolumn{3}{|c|}{ Per Cent in Range } & \multicolumn{3}{|c|}{ Per Cent in Range } \\
\hline & $\begin{array}{l}40 \\
W .\end{array}$ & $\begin{array}{l}25 \\
W\end{array}$ & $\begin{array}{l}\text { As } \\
\text { Received }\end{array}$ & $\begin{array}{l}40 \\
W\end{array}$ & $\begin{array}{l}25 \\
W\end{array}$ & $\begin{array}{l}\text { As } \\
\text { Received }\end{array}$ & $\begin{array}{l}40 \\
W\end{array}$ & $\begin{array}{l}25 \\
W\end{array}$ & $\begin{array}{l}\text { As } \\
\text { Receive } \\
\text { d }\end{array}$ & $\begin{array}{l}40 \\
W\end{array}$ & $\begin{array}{l}25 \\
W\end{array}$ & $\begin{array}{l}\text { As. } \\
\text { Received }\end{array}$ \\
\hline $\begin{array}{l}0.172 \text { to } \\
0.243\end{array}$ & 35 & - & - & - & - & - & 60 & 64 & -- & 48 & 37 & - \\
\hline $\begin{array}{l}0.243 \text { to } \\
0.344\end{array}$ & 38 & 60 & - & 60 & 57 & - & 25 & 23 & -- & 34 & 41 & 33 \\
\hline $\begin{array}{l}0.344 \text { to } \\
0.486\end{array}$ & 13 & 21 & - & 23 & 23 & - & 8 & 6 & - & 11 & 14 & 42 \\
\hline $\begin{array}{l}0.486 \text { to } \\
0.688\end{array}$ & 7 & 9 & 47 & 9 & 10 & 51 & 4 & 2 & 55 & 5 & 6 & 14 \\
\hline $\begin{array}{l}0.688 \text { to } \\
0.972\end{array}$ & 3 & 5 & 27 & 6 & 8 & 25 . & & & 23 & & & 7 \\
\hline $\begin{array}{l}0.972 \text { to } \\
1.375\end{array}$ & 1 & 3 & 13 & 1 & & 12 & & & 7 & & & 3 \\
\hline $\begin{array}{l}1.375 \text { to } \\
1.946\end{array}$ & & & 7 & & & 5 & & & 4 & & & -1 \\
\hline $\begin{array}{l}1.946 \text { to } \\
2.750\end{array}$ & & & 3 & & & 3 & & & 3 & & & \\
\hline $\begin{array}{l}2.750 \text { to } \\
3.889\end{array}$ & & & 2 & & & 3 & & & 8 & & & \\
\hline $\begin{array}{l}3.889 \text { to } \\
5.500\end{array}$ & & & 1 & & & 1 & & & & & & \\
\hline Total & 98 & 98 & 100 & 99 & 98 & 100 & 97 & 95 & 100 & 98 & 98 & 100 \\
\hline
\end{tabular}


T. A. Flament

8C720-98-JBD:001

Page 7

HNF -2729

April 23, 1998

Rev. 0

Page 20 of 28

Table A-2 Particle Volume Distribution (WHC-SP-1182, Appendix I)

\begin{tabular}{|c|c|c|c|c|c|c|c|c|c|c|c|c|}
\hline & \multicolumn{3}{|c|}{ M13T } & \multicolumn{3}{|c|}{ M13B } & \multicolumn{3}{|c|}{$\mathrm{T} 20 \mathrm{~T}$} & \multicolumn{3}{|c|}{ T20B(Duplicate) } \\
\hline \multirow{2}{*}{$\begin{array}{l}\text { Particle } \\
\text { Dia. (Dm) }\end{array}$} & \multicolumn{3}{|c|}{ Per Cent in Range } & \multicolumn{3}{|c|}{ Per Cent in Range } & \multicolumn{3}{|c|}{ Per Cent in Range } & \multicolumn{3}{|c|}{ Per Cent in Range } \\
\hline & $\begin{array}{l}40 \\
W\end{array}$ & $\begin{array}{l}25 \\
W\end{array}$ & $\begin{array}{l}\text { As } \\
\text { Received }\end{array}$ & $\begin{array}{l}40 \\
W\end{array}$ & $\begin{array}{l}25 \\
W\end{array}$ & $\begin{array}{l}\text { As } \\
\text { Receive } \\
\text { d }\end{array}$ & $\begin{array}{l}40 \\
W\end{array}$ & $\begin{array}{l}25 \\
\mathrm{~W}\end{array}$ & $\begin{array}{l}\text { As } \\
\text { Receive } \\
\text { d }\end{array}$ & $\begin{array}{l}40 \\
W\end{array}$ & 25 & $\begin{array}{l}\text { As } \\
\text { Received }\end{array}$ \\
\hline $\begin{array}{l}0.172 \text { to } \\
0.243\end{array}$ & $\begin{array}{l}0.7 \\
5 \\
\end{array}$ & - & - & -- & -- & -- & 1.8 & 1.7 & 1.2 & 0.9 & 0.8 & - \\
\hline $\begin{array}{l}0.243 \text { to } \\
0.344\end{array}$ & $\begin{array}{l}1.8 \\
0\end{array}$ & 0.8 & -- & 1.0 & 0.4 & -- & 2.1 & 1.8 & 1.3 & 2.0 & 1.8 & 1.0 \\
\hline $\begin{array}{l}0.344 \text { to } \\
0.486\end{array}$ & $\begin{array}{l}1.9 \\
0 \\
\end{array}$ & 1.0 & 0.3 & 1.0 & 1.0 & 0.8 & 2.0 & 1.6 & 1.2 & 2.0 & 1.8 & 1.0 \\
\hline $\begin{array}{l}0.486 \text { to } \\
0.688\end{array}$ & $\begin{array}{l}1.6 \\
0 \\
\end{array}$ & 1.1 & 0.8 & 1.3 & 1.1 & 0.9 & 2.1 & 1.5 & 1.3 & 1.9 & 1.8 & 1.0 \\
\hline $\begin{array}{l}0.688 \text { to } \\
0.972\end{array}$ & 2.6 & 1.6 & 1.1 & 2.0 & 1.7 & 1.2 & 2.7 & 1.9 & 1.5 & 2.7 & 2.1 & 1.4 \\
\hline $\begin{array}{l}0.972 \text { to } \\
1.375\end{array}$ & 3.4 & 2.0 & 1.6 & 2.7 & 2.1 & 1.6 & 3.7 & 2.4 & 2.1 & 3.6 & 2.8 & 1.9 \\
\hline $\begin{array}{l}1.375 \text { to } \\
1.946\end{array}$ & 4.0 & 3.2 & 1.9 & 3.2 & 2.5 & 2.1 & 3.8 & 2.8 & 2.3 & 3.9 & 3.2 & 2.1 \\
\hline $\begin{array}{l}1.946 \text { to } \\
2.750\end{array}$ & 5.0 & 4.2 & 2.3 & 3.8 & 3.5 & 2.6 & 3.9 & 3.7 & 2.2 & 4.2 & 3.6 & 2.4 \\
\hline $\begin{array}{l}2.750 \text { to } \\
3.889\end{array}$ & 6.3 & 5.5 & 4.1 & 4.8 & 4.5 & 3.8 & 5.1 & 4.6 & 4.0 & 4.9 & 4.2 & 3.2 \\
\hline $\begin{array}{l}3.889 \text { to } \\
5.500\end{array}$ & 7.4 & 7.7 & 5.9 & 6.3 & 6.0 & 5.1 & 6.5 & 6.1 & 5.4 & 5.5 & 4.7 & 4.0 \\
\hline $\begin{array}{l}5.500 \text { to } \\
7.778\end{array}$ & $\begin{array}{l}10 . \\
8\end{array}$ & $\begin{array}{l}10 . \\
6\end{array}$ & 8.7 & 8.1 & 7.7 & 6.3 & 8.1 & 7.8 & 6.5 & 7.4 & 6.5 & 5.0 \\
\hline $\begin{array}{l}7.778 \text { to } \\
11.000 \\
\end{array}$ & $\begin{array}{l}11: \\
5\end{array}$ & $\begin{array}{l}11 . \\
6\end{array}$ & 10.3 & 8.6 & 8.2 & 7.1 & 8,6 & 8.3 & 7.5 & 7.8 & 6.9 & 5.2 \\
\hline 11.000 to & 11. & 11. & 11.0 & 8.8 & 8.7 & 8.0 & 9.3 & 9.4 & 8.5. & 7.9 & 7.4 & 5.8 \\
\hline
\end{tabular}


T. A. Flament

Page 8

April 23, 1998
8C720-98-JBD:001

HNF-2729

Rev. 0

Page 2l of 28

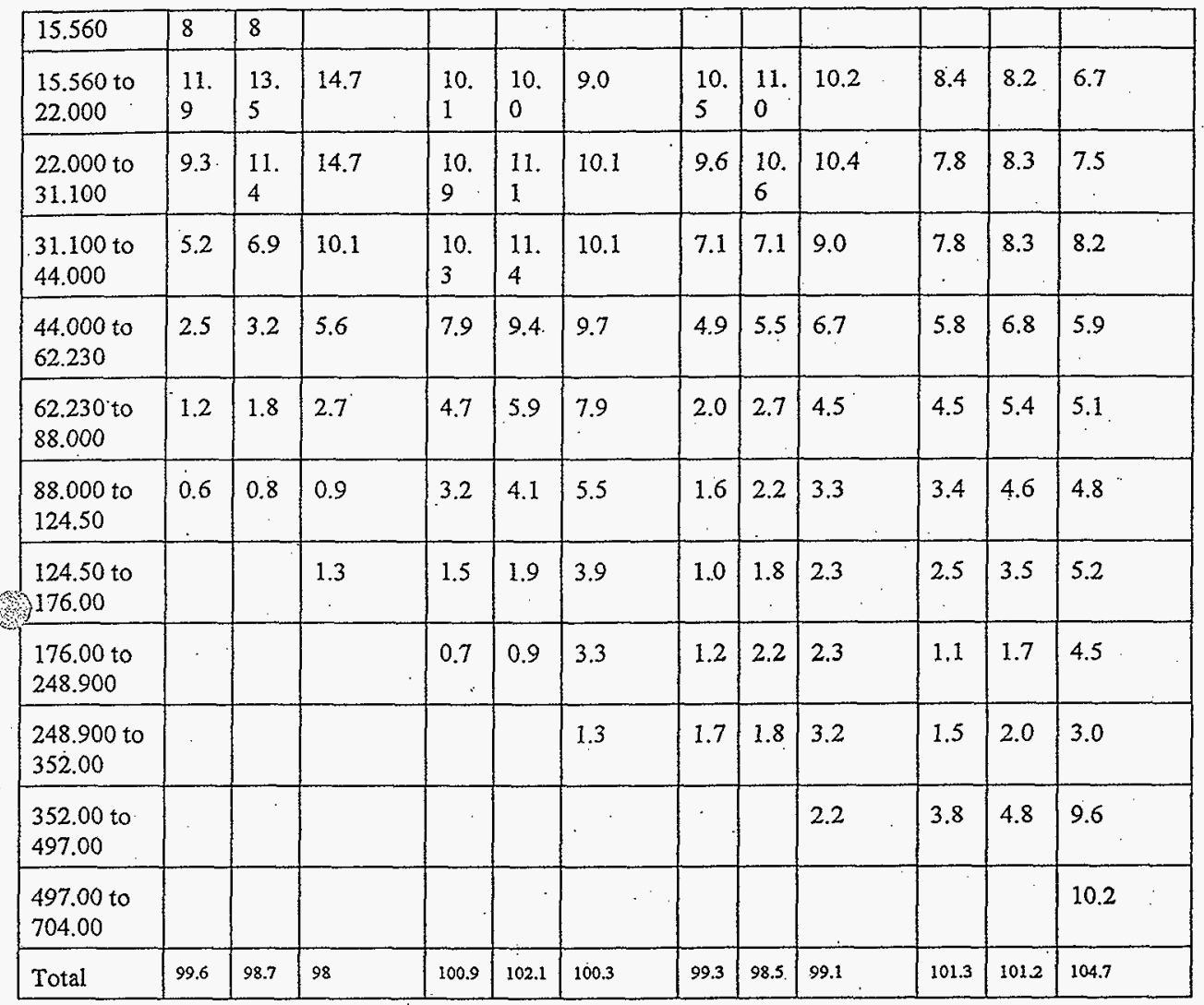


T. A. Flament

8C720-98-JBD:001

Page 9

HNF-2729

April 23, 1998

Rev. 0

Page 22 of 28

\section{APPENDIX B}

Basis for Blow Sand Particle Size

Reference: (1) Articke, K. Willeke and K.T. Whitby, J. Air Pollution Control Assoc., Vol. 25 p. 529, dated 1975.

(2) Book, Kirk-Othmer, Encyclopedia of Chemical Technology, Vol. 1 (4th Ed.), 1991.

Atmospheric aerosols may be classified into three size modes: nuclei, accumulation, and large or coarse-particle modes. The bulk of the aerosol mass usually occurs in the 0.1 to $10 \mu \mathrm{m}$ size range which encompasses most of the accumulation mode and part of the large-particle mode. From approximately $0.09 \mu \mathrm{m}$ to approximately $2.5 \mu \mathrm{m}$, particles are in the accumulation mode, while particles in the $2.5 \mu \mathrm{m}$ to $10 \mu \mathrm{m}$ range tend to have appreciable deposition velocities (KirkOthmer).

The characteristics of wind blown dust are (Willeke \& Whitby):

Table B-1 Aerosol Characteristics of $2.5 \mu \mathrm{m}$ to $10 \mu \mathrm{m}$ Particles

\begin{tabular}{|l|l|}
\hline Source & Wind Blown Dust \\
\hline Fate & Deposit \\
\hline Atmospheric Lifetime & Hours \\
\hline
\end{tabular}


PAGE 23 OF 28

\section{APPENDIX B: TESTING SCHEDULE}


HNF-2729, Rev. 0

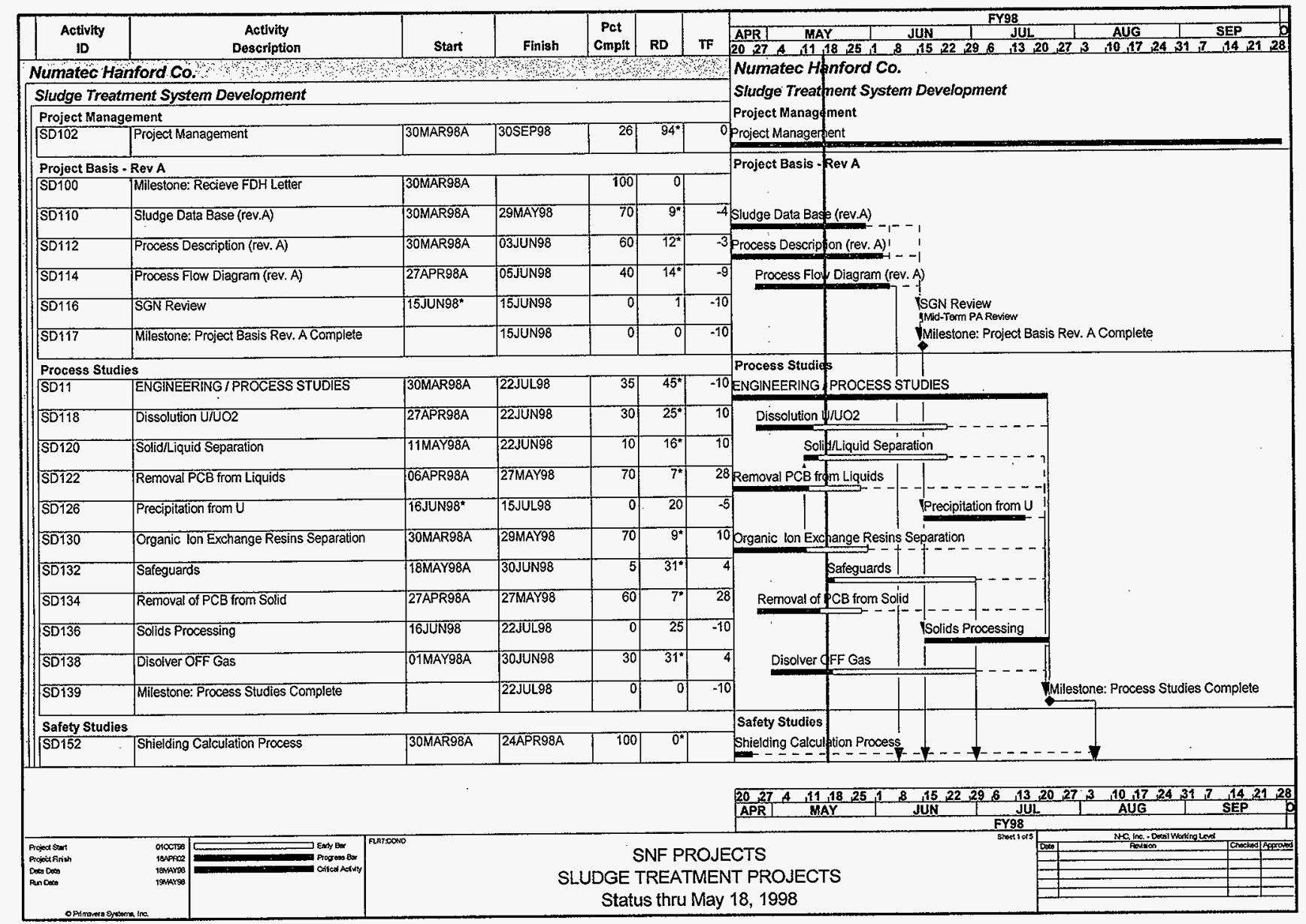

Page 24 of 28 
HNF-2729, Rev. 0

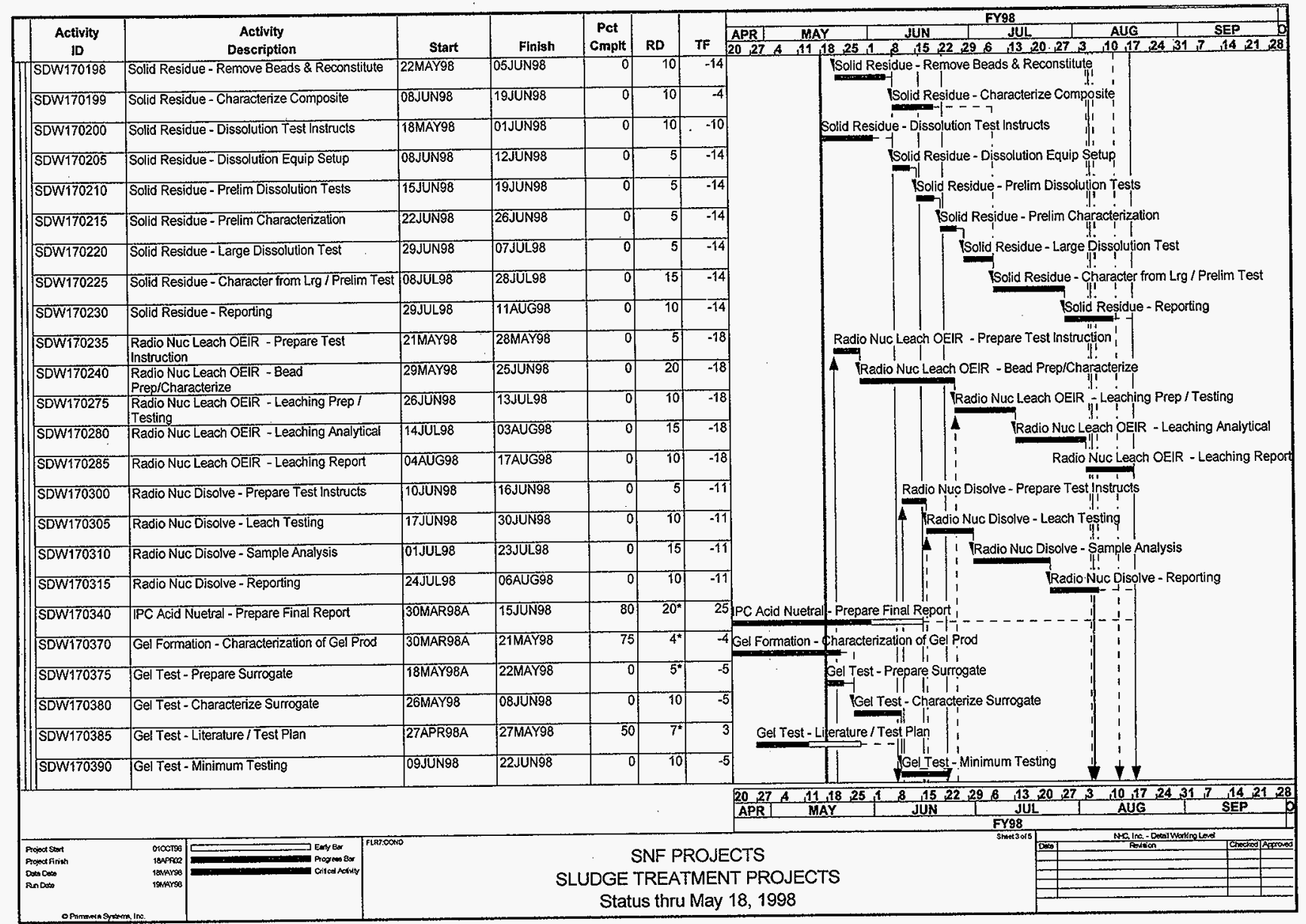

Page 25 of 28 
HNF-2729, Rev. 0

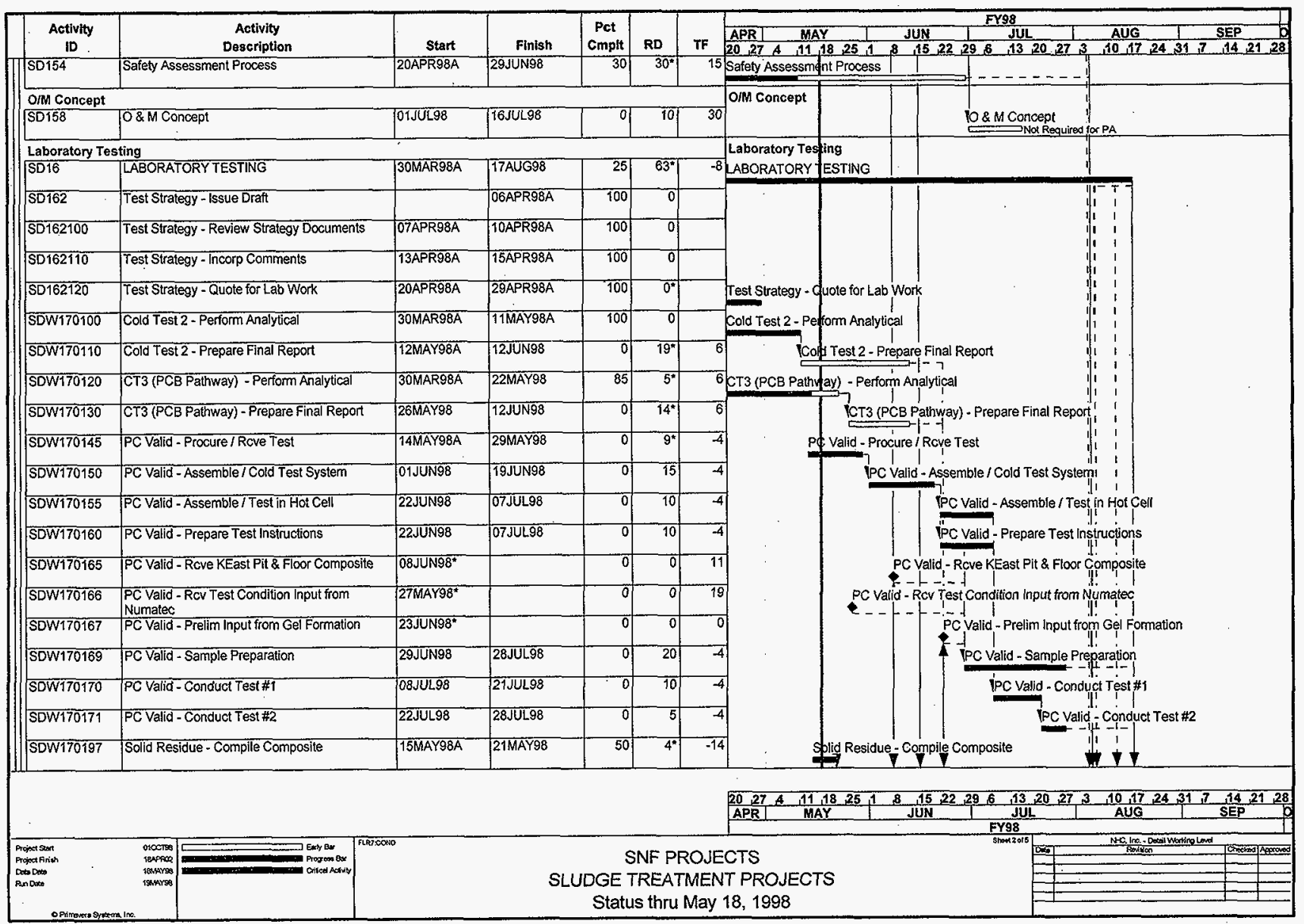

Page 26 of 28 
HNF-2729, Rev. 0

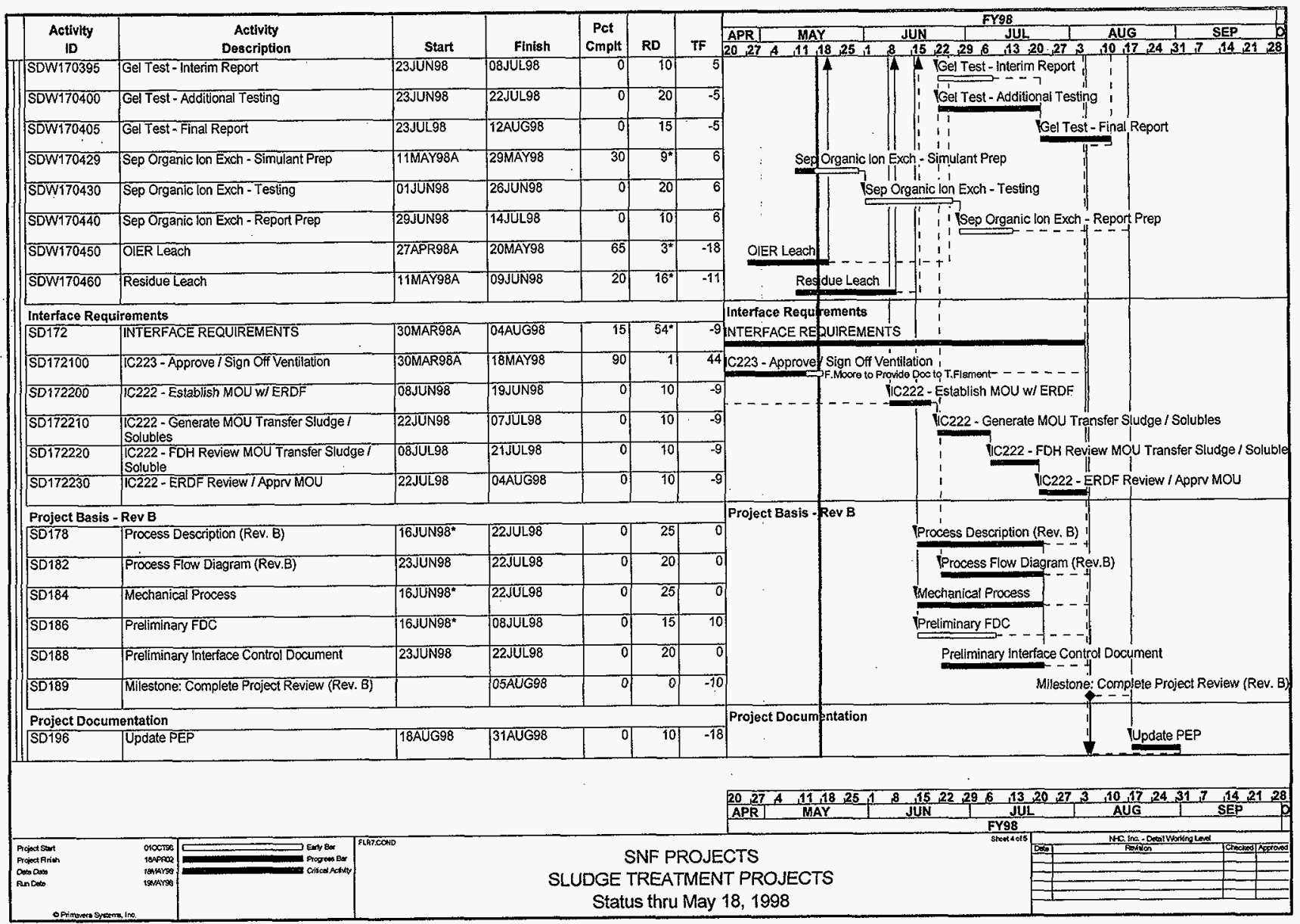

Page 27. of 28 
HNF-2729, Rev. 0

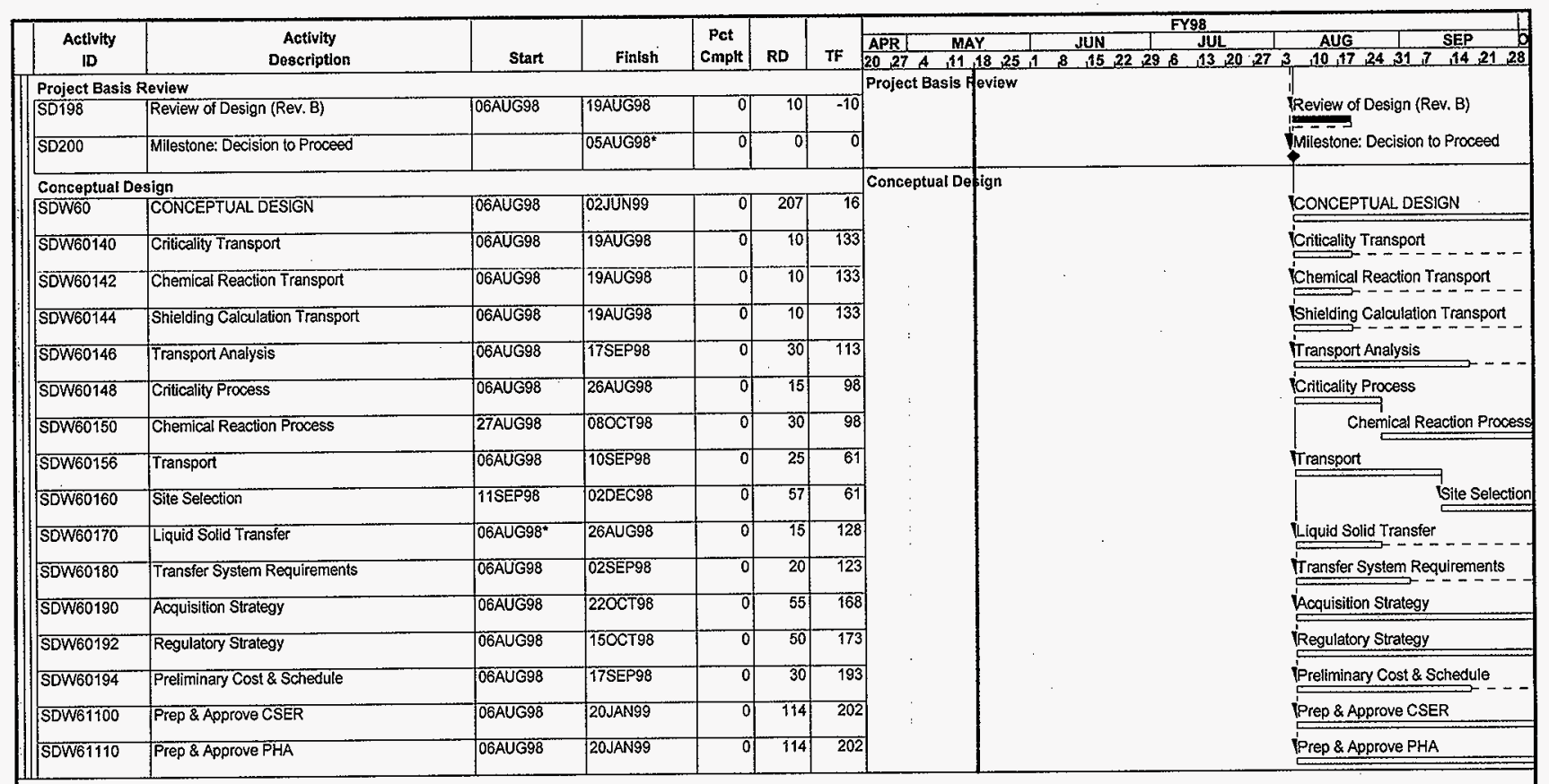

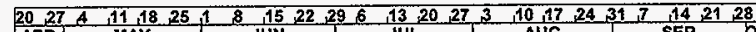

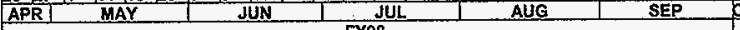

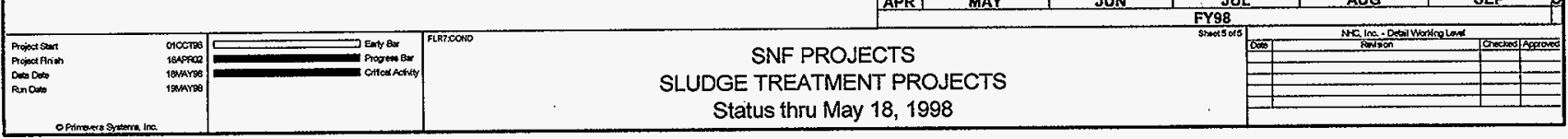

Page 28 of 28 


\section{DISTRIBUTION SHEET}

\begin{tabular}{|c|c|c|c|c|c|}
\hline \multirow{2}{*}{$\begin{array}{l}\text { To } \\
\text { Distribution }\end{array}$} & \multirow{2}{*}{\multicolumn{3}{|c|}{$\begin{array}{l}\text { From } \\
\text { Sludge Treatment Project }\end{array}$}} & \multicolumn{2}{|c|}{ Page 1 of 1} \\
\hline & & & & \multicolumn{2}{|c|}{ Date $5 / 27 / 98$} \\
\hline \multirow{2}{*}{\multicolumn{4}{|c|}{$\begin{array}{l}\text { Project Title/Work Order } \\
\text { Spent Nuclear Fue1 }\end{array}$}} & \multirow{2}{*}{\multicolumn{2}{|c|}{$\begin{array}{ll}\text { EDT No. } & 618464 \\
\text { ECN No. } & \text { N/A }\end{array}$}} \\
\hline & & & & & \\
\hline Name & MSIN & $\begin{array}{l}\text { Text } \\
\text { With All } \\
\text { Attach. }\end{array}$ & Text Only & $\begin{array}{l}\text { Attach./ } \\
\text { Appendix } \\
\text { Only } \\
\end{array}$ & $\begin{array}{l}\text { EDT/ECN } \\
\text { Only }\end{array}$ \\
\hline $\begin{array}{l}\text { J. Bourges } \\
\text { D. A. Dodd } \\
\text { J. B. Duncan } \\
\text { T. A. Flament } \\
\text { D. L. Herting } \\
\text { J. R. Jewett } \\
\text { W. C. Mil er } \\
\text { W. W. Rutherford } \\
\text { M. J. Schliebe } \\
\text { A. J. Schmidt } \\
\text { K. L. Silvers } \\
\text { W. I. Winters } \\
\text { K. S. Witwer } \\
\text { Central FiTes (original +1) }\end{array}$ & $\begin{array}{l}\text { T6-07 } \\
T 6-50 \\
H 7-20 \\
H 7-20 \\
\text { T6-07 } \\
\text { T6-07 } \\
\text { H5-25 } \\
\text { H7-20 } \\
\text { L6-13 } \\
\text { K2-12 } \\
\text { K9-08 } \\
\text { T6-50 } \\
\text { L6-13 } \\
\text { B } 1-07 \\
\end{array}$ & 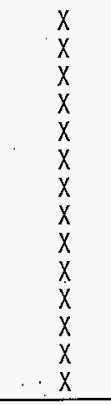 & & & \\
\hline
\end{tabular}

